\title{
CROP MANAGEMENT AND ITS EFFECTS ON WEED OCCURRENCE
}

\author{
Marco Aurélio CASTRO ${ }^{1}$ iD, Sebastião Ferreira de LIMA $^{2}$ iD, Germison Vital TOMQUELSKI ${ }^{3}$ (D), \\ Maria Gabriela de Oliveira ANDRADE ${ }^{4}$, Jordana Dias MARTINS² ic
}

\footnotetext{
${ }^{1}$ Postgraduate Program in Agronomy, Federal University of Mato Grosso do Sul, Chapadão do Sul, MS, Brazil.

2 Department of Agronomy, Federal University of Mato Grosso do Sul, Chapadão do Sul, MS, Brazil.

3 Private Practice, Chapadão do Sul, MS, Brazil.

${ }^{4}$ Postgraduate Program in Agronomy, São Paulo State University, Botucatu, SP, Brazil.
}

Corresponding author:

Sebastião Ferreira de Lima

Email: sebastiao.lima@ufms.br

How to cite: CASTRO, M.A., et al. Crop management and its effects on weed occurrence. Bioscience Journal. 2021, 37, e37012. https://doi.org/10.14393/BJ-v37n0a2021-48271

\begin{abstract}
The objective was to evaluate weed phytosociology and similarities between crop management systems in the Chapadões region. The experiment was conducted at in agricultural area located in the municipality of Chapadão do Sul, MS, during the 2016/17 harvest. Three crop managements strategies were used: (1) cotton/soybean/Urochloa, (2) millet/soybean/millet and (3) millet/soybean/crotalaria. A phytosociological survey of weeds was carried out during soybean cultivation and cover crops growth, in succession. The evaluation area for each management strategy was 0.5 ha. Soybean surveys were carried out in October and January, while the cover crop surveys were performed in February and May. The relative frequency (RF), relative density (RD), relative abundance (AR), and relative importance (RI) of weeds, Venn diagram, and Jaccard and Sorenson similarity indices were evaluated. The management area represented by the cotton/soybean/Urochloa rotation had fewer weed species than others. The species Cenchrus echinatus, Digitaria insularis, Digitaria sanguinalis, Eleusine indica and Commelina benghalensis had the highest phytosociological indeces among the monocotyledons. Attention is required for managing the dicotyledons Amaranthus deflexus, Conyza canadensis and Senna obtusifolia despite their low indices because of herbicide resistant cases. The highest indeces of similarity were found between managements areas 2 and 3 , which did not rely on cotton cultivation prior to soybeans.
\end{abstract}

Keywords: Germination Flow. Monocotyledons. Phytosociology. Seed Bank.

\section{Introduction}

Competition with weeds affects crop development by reducing access to resources such as water, light, and nutrients (Brighenti 2010), thereby resulting in decreased crop productivity (Braz et al. 2010) and consequently, economic losses (Vendruscolo et al. 2017). Identifying species as well as understanding their cycles, propagation methods, and growth habits within conventional or direct sowing systems enables the adoption of management strategies, thus minimizing losses (Adegas et al. 2010; Santos et al. 2015), which can range from $23 \%-70 \%$ of grain productivity (Vidal and Merotto Júnior 2001). In cultivated areas with different cultures, monocot and dicot weed species have been observed to be predominantly from the families Poaceae and Asteraceae, respectively (Silva et al. 2019; Ávila et al. 2020; Machado et al., 2020; Santos et al. 2015; Schmidt et al. 2020). 
It is important to study weed communities (Pitelli 2015) to understand competition between them. It is important to examine whether competition is intraspecific or interspecific in order to devise more efficient control strategies (Santos et al. 2015), because no single herbicide has sufficient action spectrum to control all weed species (Brighenti et al. 2003). Thus, knowledge of weed communities in cultivated areas can facilitate their chemical management. It is important to note that the use of herbicides can have a major effect on production costs (Richetti 2015), can affect entire ecosystems (Myers et al. 2016; Van Bruggen et al. 2018), and can select weeds in the area, due to successive application of glyphosate. (Procópio et al. 2007). It is therefore important to prioritize the diversified use of herbicides with different active principles (Soares et al. 2010).

Knowledge of species diversity is important to understanding weed dynamics in relation to crops during different growing seasons. To gain this knowledge, phytosociological surveying is performed, which comprises the study of plant communities to establish a comprehensive understanding of the composition and distribution of plant species in an area (Guglieri-Caporal et al. 2010; Concenço et al. 2013). However, when crop rotation or succession is performed, it is necessary to determine which crops will result in a positive relationship of phytosociological indices for weed management (Ferreira et al. 2010).

Occupying agricultural areas with off-season crops potentiates weed suppression compared to allowing areas to remain fallow (Lima et al. 2014). Alternate cultivation systems can be adopted such as harvest/interim/harvest, or harvest/green/manure. The mulch left by the previous crop is a physical control, which has an important role in weed control (Castro et al. 2011). The total weed population can be significantly affected by mulch levels (Lima et al. 2014), regardless of the presence of herbicide, or the evaluation period. Each ton of cover added to the soil can lead to the control of $\sim 4.0 \%$ of the total weeds (Oliveira et al. 2001).

Understanding germinal flow dynamics, phytosociological characteristics of weeds within a complex production system characterized by large agricultural areas, and associated management strategies (ranging from crop rotation or succession to the rotation of active ingredients) facilitates formulation of the most appropriate weed management strategies. Thus, the objective of this study was to evaluate weed phytosociology and similarities between crop management systems in the Chapadões region.

\section{Material and Methods}

The study was performed in the Fazenda Campo Bom agricultural area, located in the municipality of Chapadão do Sul, MS, which has an average altitude of $810 \mathrm{~m}$, during the 2016/2017 harvest. The climate is humid tropical (Aw) according to the Köppen classification, with well-defined seasons; a dry period exists from May-September (autumn/winter), and rainfall happens from October-April (spring/summer). Its annual temperature varies between $13^{\circ} \mathrm{C}$ and $28^{\circ} \mathrm{C}$, average precipitation is $1,850 \mathrm{~mm}$, and average annual relative humidity is $64.8 \%$ (Castro et al. 2012). Rainfall data and monthly air temperature were recorded during the experiment (Figure 1).

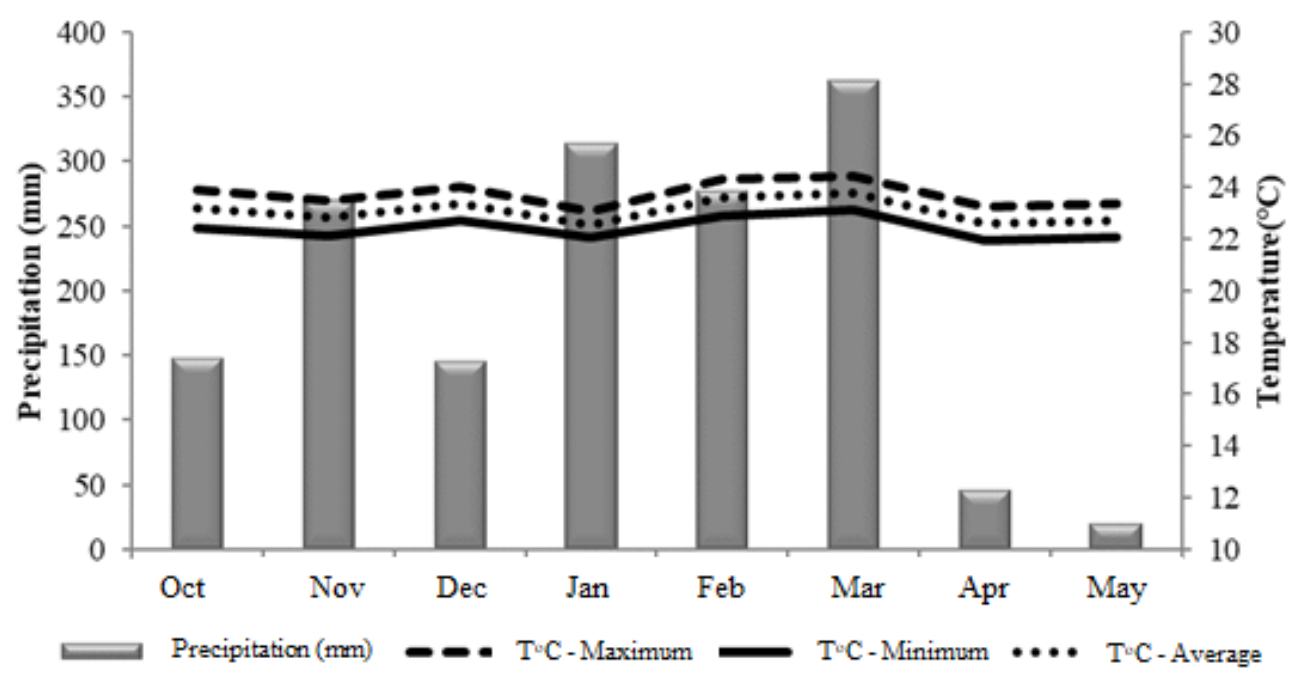

Figure 1. Precipitation $(\mathrm{mm})$ and average monthly temperature $(\stackrel{\circ}{ } \mathrm{C})$ during the study period. 
Three crop management strategies were used to assess the germinal flows and to characterize the phytosociological indices: (1) cotton/soybean/Urochloa decumbens; (2) millet/soybean/millet; and (3) millet/soybean/Crotalaria. The phytosociological surveys were carried out during soybean crop management, and in cover crops during soybean succession. During the soybean crop cultivation, phytosociological surveys of weeds occurred in October, 15 days after emergence (DAE) while the crop was in stage V2, and in January, at 95 DAE with the crop in stage R7.

For the soybean harvest, the area was desiccated, and the cover crops were then planted in the management groups (1) U. decumbens, (2) millet, and (3) Crotalaria. Phytosociological weed surveys in the cover crops were then carried out in February and May.

For the weed survey, 0.5 ha areas were demarcated for each management group. Glyphosate potassium and Clethodim herbicides were used during soybean cultivation.

To measure and identify the weed species present in the evaluation area, Braun-Blanquet's (1979) square method was used, which involves randomly choosing and evaluating $1 \mathrm{~m}^{2}$. The frequency, relative frequency, density, relative density, abundance, relative abundance, and relative importance index for each species were then calculated for each system, and for each weed, according to the formulas proposed by the Mueller-Dombois and Ellenberg (1974) methodology.

$$
\begin{gathered}
\text { Frequency }(F)=\frac{\text { no. of squares where the species was found }}{\text { total no. of squares }} \\
\text { Relative Frequency }(\mathrm{RF})=\frac{\text { frequency of the species } \mathrm{x} 100}{\text { total frequency of the species }} \\
\text { Density (D) }=\frac{\text { total no. of individuals of a species }}{\text { total no. of squares }} \\
\text { Relative Density (RD) }=\frac{\text { density of the species } x 100}{\text { total density of the species }} \\
\text { Abundance (A) }=\frac{\text { total no. of individuals of a species }}{\text { total no. of squares where the species was found }} \\
\text { Relative } A \text { bundance (RA) }=\frac{\text { abundance of the species } x 100}{\text { total abundance of the species }}
\end{gathered}
$$$$
\text { Relative Importance Index }(\mathrm{RI})=(\mathrm{RF})+(\mathrm{RD})+(\mathrm{RA})
$$

A floristic similarity analysis was also carried out using a Venn diagram (Figure 2), which uses superimposed circles to illustrate the logical relationships between two or more sets of items, highlighting how the items are similar and different. The DivEs v4.0 program (Rodrigues 2017) was also used to calculate the Sorensen (SI) and Jaccard (JS) similarity indices (Table 5), and provided the calculated floristic similarity between the three management areas during the surveyed months; index values range from 0-1; 1 when all species are common and 0 when there are no common species (Odum 1985).

\section{Results}

A total of 4267 weeds, comprising 25 species and distributed in 12 families (Table 1), were recorded in the weed community surveyed during the studied months. Where soybeans were present monocotyledon classes prevailed, comprising $81 \%$ of species. For the cover crops Urochloa decumbens, millet, and Crotalaria, the dicotyledons predominated, comprising $52 \%$ of the weeds found, in relation to monocotyledons (48\%). 
Table 1. Scientific names, common names, families, and botanical classes of the 25 weed species found in the rotation system. Chapadão do Sul, MS, 2016/2017.

\begin{tabular}{lcc}
\hline Scientific name & Family & Class \\
\hline Urochloa decumbens & Poaceae & Monocotyledon \\
Urochloa mutica & Poaceae & Monocotyledon \\
Cenchrus echinatus & Poaceae & Monocotyledon \\
Digitaria insularis & Poaceae & Monocotyledon \\
Digitaria sanguinalis & Poaceae & Monocotyledon \\
Eleusine indica & Poaceae & Monocotyledon \\
Eragrostis pilosa & Poaceae & Monocotyledon \\
Pennisetum purpureum & Poaceae & Monocotyledon \\
Commelina benghalensis & Commelinaceae & Monocotyledon \\
Cyperus rotundus & Cyperaceae & Monocotyledon \\
Alternanthera tenella & Amaranthaceae & Dicotyledone \\
Amaranthus deflexus & Amaranthaceae & Dicotyledone \\
Acanthospermum hispidum & Asteraceae & Dicotyledone \\
Bidens pilosa & Asteraceae & Dicotyledone \\
Conyza canadensis & Asteraceae & Dicotyledone \\
Taraxacum officinale & Asteraceae & Dicotyledone \\
Ageratum conyzoides & Asteraceae & Dicotyledone \\
Ipomoea triloba & Convolvulaceae & Dicotyledone \\
Chamaesyce hirta & Euphorbiaceae & Dicotyledone \\
Euphorbia heterophylla & Euphorbiaceae & Dicotyledone \\
Senna obtusifolia & Fabaceae & Dicotyledone \\
Sida rhombifolia & Malvaceae & Dicotyledone \\
Phyllanthus niruri & Phyllantaceae & Dicotyledone \\
Portulaca oleracea & Portulacaceae & Dicotyledone \\
Richardia brasiliensis & Rubiaceae & Dicotyledone \\
\hline
\end{tabular}

In the first weed survey for soybean crop at $15 \mathrm{DAE}$, the number of species found in management area 1 (cotton/soybean/Urochloa) was lower than found in treatments 2 (millet/soybean/millet) and 3 (millet/soybean/Crotalaria) (Table 2). Thus, the first survey in management area 1 demonstrated that weeds such as $D$. insularis, $E$. indica, and C. benghalensis, (with relative frequency and density indices above $10 \%$ (Table 2)) are plants that are well distributed, and have high populations in the area; this fact was maintained in the last survey with the inclusion of $D$. sanguinalis (Table 3 ).

At $95 \mathrm{DAE}$, S. obtusifolia was observed within management areas 2 and 3, with frequency and density indices of $45.3 \%$ and $14.2 \%$, respectively (Table 3 ); indices increased in relation to soybean development (Tables 2 and 3 ).

Table 2. Species, relative frequency (RF), relative density (RD), relative abundance (RA), and relative importance (RI) of weeds under different management strategies at 15 DAE in a soybean crop in Chapadão do Sul, MS, 2016/2017.

\begin{tabular}{|c|c|c|c|c|c|c|c|c|c|c|c|c|}
\hline \multicolumn{13}{|l|}{ October (15 DAE) } \\
\hline \multirow{4}{*}{ Species } & \multicolumn{4}{|c|}{ Management 1} & \multicolumn{4}{|c|}{ Management 2} & \multicolumn{4}{|c|}{ Management 3} \\
\hline & \multicolumn{4}{|c|}{ Cotton/Soy/Urochloa } & \multicolumn{4}{|c|}{ Millet/Soy/Millet } & \multicolumn{4}{|c|}{ Millet/Soy/Crotalaria } \\
\hline & RF & $\mathrm{RD}$ & RA & IR & RF & $\mathrm{RD}$ & RA & IR & RF & $\mathrm{RD}$ & RA & IR \\
\hline & $\%$ & $\%$ & $\%$ & $\%$ & $\%$ & $\%$ & $\%$ & $\%$ & $\%$ & $\%$ & $\%$ & $\%$ \\
\hline B. decumbens & - & - & - & - & - & - & - & - & 3.2 & 2.4 & 9.0 & 14.6 \\
\hline C. echinatus & - & - & - & - & 3.0 & 0.4 & 1.3 & 4.7 & 12.9 & 51.8 & 48.2 & 112.9 \\
\hline D. insularis & 17.1 & 17.8 & 19.9 & 54.8 & 11.9 & 40.0 & 34.7 & 86.6 & - & - & - & - \\
\hline E. indica & 22.9 & 56.5 & 47.3 & 126.7 & 11.9 & 23.7 & 20.5 & 56.2 & 11.3 & 6.6 & 7.0 & 24.9 \\
\hline E. pilosa & - & - & - & - & 3.0 & 0.3 & 0.9 & 4.1 & - & - & - & - \\
\hline P. purpureum & - & - & - & - & 4.5 & 1.2 & 2.7 & 8.3 & - & - & - & - \\
\hline C. benghalensis & 22.9 & 18.4 & 15.4 & 56.7 & 11.9 & 14.0 & 12.1 & 38.0 & 12.9 & 13.2 & 12.3 & 38.4 \\
\hline C. rotundus & - & - & - & - & 7.5 & 3.0 & 4.1 & 14.6 & - & - & - & - \\
\hline A. deflexus & 5.7 & 2.4 & 7.9 & 16.0 & 9.0 & 2.8 & 3.3 & 15.1 & 3.2 & 0.4 & 1.7 & 5.3 \\
\hline B. pilosa & 8.6 & 2.1 & 4.7 & 15.3 & - & - & - & - & 3.2 & 0.5 & 2.0 & 5.8 \\
\hline C. canadenses & 8.6 & 1.0 & 2.3 & 12.0 & & & & & & & & \\
\hline A. conyzoides & - & - & - & - & 4.5 & 0.9 & 2.1 & 7.5 & 8.1 & 9.4 & 13.9 & 31.4 \\
\hline
\end{tabular}




\begin{tabular}{lcccccccccccc} 
I. triloba & 14.3 & 1.8 & 2.5 & 18.6 & 7.5 & 1.6 & 2.2 & 11.2 & 8.1 & 4.5 & 6.6 & 19.2 \\
C. hirta & - & - & - & - & 3.0 & 0.4 & 1.3 & 4.7 & - & - & - & - \\
E. heterophylla & - & - & - & - & - & - & - & - & 8.1 & 1.4 & 2.1 & 11.6 \\
S. obtusifolia & - & - & - & - & 7.5 & 1.4 & 2.0 & 10.9 & 9.7 & 2.2 & 2.8 & 14.7 \\
S. rhombifolia & - & - & - & - & 9.0 & 7.5 & 8.7 & 25.1 & 8.1 & 3.3 & 4.9 & 16.3 \\
P. oleracea & - & - & - & - & 3.0 & 0.8 & 2.7 & 6.5 & - & - & - & - \\
R. brasiliensis & - & - & - & - & 3.0 & 2.2 & 7.6 & 12.8 & 11.3 & 4.3 & 4.6 & 20.1 \\
\hline
\end{tabular}

Table 3. Species, relative frequency (RF), relative density (RD), relative abundance (RA), and relative importance (RI) of weeds under different management strategies at 95 DAE in a soybean crop in Chapadão do Sul, MS, 2016/2017.

\begin{tabular}{|c|c|c|c|c|c|c|c|c|c|c|c|c|}
\hline \multicolumn{13}{|l|}{ January (95 DAE) } \\
\hline \multirow{4}{*}{ Species } & \multicolumn{4}{|c|}{ Management 1} & \multicolumn{4}{|c|}{ Management 2} & \multicolumn{4}{|c|}{ Management 3} \\
\hline & \multicolumn{4}{|c|}{ Cotton/Soy/Urochloa } & \multicolumn{4}{|c|}{ Millet/Soy/Millet } & \multicolumn{4}{|c|}{ Millet/Soy/Crotalaria } \\
\hline & RF & $\mathrm{RD}$ & RA & IR & RF & $\mathrm{RD}$ & RA & IR & RF & $\mathrm{RD}$ & RA & IR \\
\hline & $\%$ & $\%$ & $\%$ & $\%$ & $\%$ & $\%$ & $\%$ & $\%$ & $\%$ & $\%$ & $\%$ & $\%$ \\
\hline U. decumbens & 3.1 & 0.3 & 1.1 & 4.6 & - & - & - & - & - & - & - & - \\
\hline D. insularis & 12.5 & 39.6 & 33.6 & 85.7 & 20.0 & 31.9 & 23.3 & 75.3 & 13.3 & 73.1 & 71.5 & 157.9 \\
\hline D. sanguinalis & 12.5 & 13.4 & 11.4 & 37.3 & 6.7 & 8.3 & 18.3 & 33.3 & - & - & - & - \\
\hline E. indica & 9.4 & 2.0 & 2.3 & 13.7 & 16.7 & 11.1 & 9.7 & 37.5 & 11.7 & 5.7 & 6.4 & 23.7 \\
\hline C. benghalensis & 21.9 & 9.7 & 4.7 & 36.3 & 13.3 & 12.5 & 13.7 & 39.5 & 13.3 & 7.8 & 7.6 & 28.7 \\
\hline A. deflexus & 9.4 & 13.4 & 15.2 & 38.0 & - & - & - & - & - & - & - & - \\
\hline B. pilosa & 6.3 & 14.4 & 24.5 & 45.2 & - & - & - & - & - & - & - & - \\
\hline A. conyzoides & - & - & - & - & 3.3 & 1.4 & 6.1 & 10.8 & 8.3 & 0.3 & 0.4 & 9.0 \\
\hline I. triloba & 3.1 & 0.3 & 1.1 & 4.6 & 13.3 & 9.7 & 10.6 & 33.7 & 8.3 & 1.8 & 2.8 & 13.0 \\
\hline E. heterophylla & - & - & - & - & 3.3 & 1.4 & 6.1 & 10.8 & 8.3 & 1.3 & 2.0 & 11.7 \\
\hline S. obtusifolia & - & - & - & - & 13.3 & 15.3 & 16.7 & 45.3 & 10.0 & 1.8 & 2.4 & 14.2 \\
\hline S. rhombifolia & 6.3 & 1.3 & 2.3 & 9.9 & 3.3 & 5.6 & 24.3 & 33.2 & 8.3 & 5.7 & 8.9 & 23.0 \\
\hline P. oleracea & - & - & - & - & 3.3 & 1.4 & 6.1 & 10.8 & - & - & - & - \\
\hline R. brasiliensis & 15.6 & 5.4 & 3.6 & 24.6 & 3.3 & 1.4 & 6.1 & 10.8 & 11.7 & 0.8 & 0.9 & 13.3 \\
\hline
\end{tabular}

Within the system using soybean, followed by $U$. decumbens (management area 1 ), C. echinatus, $D$. sanguinalis, and $E$. indica showed RD indices higher than the RF and IR indices $>40 \%$ (Table 4). This behavior was maintained for $D$. sanguinalis in the May evaluation (Table 5).

Table 4. Species, relative frequency (RF), relative density (RD), relative abundance (RA), and relative importance (IR) of weeds in crop succession in Chapadão do Sul, MS, 2016/2017.

\begin{tabular}{|c|c|c|c|c|c|c|c|c|c|c|c|c|}
\hline \multicolumn{13}{|l|}{ February } \\
\hline \multirow{4}{*}{ Species } & \multicolumn{4}{|c|}{ Management 1} & \multicolumn{4}{|c|}{ Management 2} & \multicolumn{4}{|c|}{ Management 3} \\
\hline & \multicolumn{4}{|c|}{ Cotton/Soy/Urochloa } & \multicolumn{4}{|c|}{ Millet/Soy/Millet } & \multicolumn{4}{|c|}{ Millet/Soy/Crotalaria } \\
\hline & $\mathrm{RF}$ & RD & RA & IR & RF & $\mathrm{RD}$ & RA & IR & $\mathrm{RF}$ & RD & RA & IR \\
\hline & $\%$ & $\%$ & $\%$ & $\%$ & $\%$ & $\%$ & $\%$ & $\%$ & $\%$ & $\%$ & $\%$ & $\%$ \\
\hline C. echinatus & 10.0 & 31.9 & 41.0 & 82.8 & 5.9 & 10.0 & 17.9 & 33.8 & 7.0 & 39.5 & 60.6 & 107.2 \\
\hline D. insularis & - & - & - & - & 11.8 & 16.7 & 15.0 & 43.4 & 11.3 & 6.2 & 5.9 & 23.4 \\
\hline D. sanguinalis & 20.0 & 28.9 & 18.6 & 67.5 & - & - & - & - & 9.9 & 4.9 & 5.4 & 20.2 \\
\hline E. indica & 10.0 & 14.8 & 19.0 & 43.9 & - & - & - & - & 9.9 & 1.2 & 1.4 & 12.4 \\
\hline C. benghalensis & 20.0 & 15.6 & 10.0 & 45.6 & 14.7 & 12.2 & 8.8 & 35.7 & 11.3 & 25.9 & 24.9 & 62.1 \\
\hline C. rotundus & 10.0 & 0.7 & 1.0 & 11.7 & 5.9 & 5.6 & 10.0 & 21.4 & - & - & - & - \\
\hline A. tenella & - & - & - & - & 5.9 & 2.2 & 4.0 & 12.1 & - & - & - & - \\
\hline A. deflexus & 10.0 & 5.9 & 7.6 & 23.5 & - & - & - & - & - & - & - & - \\
\hline A. hispidum & - & - & - & - & - & - & - & - & - & - & - & - \\
\hline B. pilosa & 10.0 & 0.7 & 1.0 & 11.7 & - & - & - & - & - & - & - & - \\
\hline C. canadenses & - & - & - & - & - & - & - & - & 2.8 & 1.2 & 4.7 & 8.8 \\
\hline A. conyzoides & - & - & - & - & 5.9 & 4.4 & 8.0 & 18.3 & 9.9 & 9.9 & 10.8 & 30.6 \\
\hline I. triloba & - & - & - & - & 14.7 & 27.8 & 19.9 & 62.4 & 7.0 & 1.2 & 1.9 & 10.2 \\
\hline C. hirta & - & - & - & - & 5.9 & 6.7 & 12.0 & 24.5 & - & - & - & - \\
\hline E. heterophylla & - & - & - & - & 8.8 & 4.4 & 5.3 & 18.6 & 5.6 & 3.7 & 7.1 & 16.4 \\
\hline S. obtusifolia & - & - & - & - & 8.8 & 5.6 & 6.6 & 21.0 & 7.0 & 1.2 & 1.9 & 10.2 \\
\hline S. rhombifolia & - & - & - & - & 5.9 & 2.2 & 4.0 & 12.1 & 11.3 & 1.2 & 1.2 & 13.7 \\
\hline P. niruri & - & - & - & - & 5.9 & 2.2 & 4.0 & 12.1 & - & - & - & - \\
\hline
\end{tabular}


Table 5. Species, relative frequency (RF), relative density (RD), relative abundance (RA), and relative importance (IR) of weeds in crop succession in Chapadão do Sul, MS, 2016/2017.

\begin{tabular}{|c|c|c|c|c|c|c|c|c|c|c|c|c|}
\hline \multicolumn{13}{|l|}{ May } \\
\hline \multirow{4}{*}{ Species } & \multirow{2}{*}{\multicolumn{4}{|c|}{$\begin{array}{c}\text { Management } 1 \\
\text { Cotton/Soy/Urochloa }\end{array}$}} & \multirow{2}{*}{\multicolumn{4}{|c|}{$\begin{array}{l}\text { Management } 2 \\
\text { Millet/Soy/Millet }\end{array}$}} & \multirow{2}{*}{\multicolumn{4}{|c|}{$\begin{array}{c}\text { Management } 3 \\
\text { Millet/Soy/Crotalaria }\end{array}$}} \\
\hline & & & & & & & & & & & & \\
\hline & $\mathrm{RF}$ & $\mathrm{RD}$ & RA & IR & $\mathrm{RF}$ & $\mathrm{RD}$ & RA & IR & $\mathrm{RF}$ & $\mathrm{RD}$ & RA & IR \\
\hline & $\%$ & $\%$ & $\%$ & $\%$ & $\%$ & $\%$ & $\%$ & $\%$ & $\%$ & $\%$ & $\%$ & $\%$ \\
\hline U. mutica & - & - & - & - & - & - & - & - & 1.4 & 0.4 & 2.4 & 4.1 \\
\hline C. echinatus & - & - & - & - & 21.1 & 5.1 & 3.1 & 29.3 & - & - & - & - \\
\hline D. insularis & - & - & - & - & - & - & - & - & 8.5 & 4.4 & 4.5 & 17.4 \\
\hline D. sanguinalis & 25.0 & 16.0 & 19.4 & 60.4 & 10.5 & 2.6 & 3.1 & 16.2 & 5.6 & 20.0 & 30.9 & 56.6 \\
\hline E. indica & - & - & - & - & 10.5 & 66.7 & 80.6 & 157.8 & 8.5 & 4.2 & 4.3 & 17.0 \\
\hline C. benghalensis & 25.0 & 16.0 & 19.4 & 60.4 & - & - & - & - & 7.0 & 1.9 & 2.4 & 11.3 \\
\hline C. rotundus & - & - & - & - & - & - & - & - & 1.4 & 0.2 & 1.2 & 2.8 \\
\hline A. tenella & - & - & - & - & - & - & - & - & 2.8 & 0.6 & 1.8 & 5.2 \\
\hline A. deflexus & - & - & - & - & - & - & - & - & 2.8 & 2.7 & 8.3 & 13.7 \\
\hline B. pilosa & 37.5 & 64.0 & 51.6 & 153.1 & - & - & - & - & 1.4 & 0.6 & 3.5 & 5.5 \\
\hline C. canadenses & - & - & - & - & - & - & - & - & 2.8 & 0.4 & 1.2 & 4.4 \\
\hline T. officinale & - & - & - & - & - & - & - & - & 1.4 & 0.2 & 1.2 & 2.8 \\
\hline A. conyzoides & - & - & - & - & - & - & - & - & 11.3 & 33.0 & 25.5 & 69.7 \\
\hline l. triloba & - & - & - & - & 26.3 & 23.1 & 11.2 & 60.5 & 5.6 & 3.0 & 4.7 & 13.4 \\
\hline C. hirta & 12.5 & 4.0 & 9.7 & 26.2 & - & - & - & - & 11.3 & 9.7 & 7.5 & 28.5 \\
\hline E. heterophylla & - & - & - & - & 15.8 & 2.6 & 2.1 & 20.4 & 11.3 & 9.7 & 7.5 & 28.5 \\
\hline S. obtusifolia & - & - & - & - & - & - & - & - & 11.3 & 12.4 & 9.6 & 33.2 \\
\hline S. rhombifolia & - & - & - & - & - & - & - & - & 1.4 & 0.4 & 2.4 & 4.1 \\
\hline P. niruri & - & - & - & - & - & - & - & - & 1.4 & 0.2 & 1.2 & 2.8 \\
\hline P. oleracea & - & - & - & - & - & - & - & - & 2.8 & 0.8 & 2.4 & 5.9 \\
\hline R. brasiliensis & - & - & - & - & - & - & - & - & 9.9 & 4.8 & 4.2 & 18.8 \\
\hline
\end{tabular}

Soybeans were cultivated from October-January, for which the Venn diagram showed three common weeds among the three treatments studied (Figure 2): E. indica, C. benghalensis, and I. triloba. However, the interactions over the months for which the crop covers were present showed $C$. echinatus and $C$. benghalensis occurring in isolation in February, and D. sanguinalis in May.

The Jaccard and Sorensen similarity indices (Table 6) contribute to understanding the Venn diagram (Figure 2). The similarity coefficient varies from 0 to 1 , being maximum when all species are common to both managements and minimum when there are no common species. The Venn diagram allows the visualization of which species were interacting in different management areas. There is a strong similarity between the management areas during soybean conduction, and higher coefficients at the end of cultivation (January); less similarity was seen between management areas 1 and 3. During the planting of cover, the coefficient values were lower, with the greatest similarity observed at the beginning of cultivation (February) (Table 6).

The Venn diagram (Figure 2) shows a greater diversity of species during planting of the soybean crop, with greater similarity between species at the beginning and end of the cultivation, when compared to the coverage crops. Of the weed species that occurred simultaneously in the three management areas, 4 and 6 species were found at the beginning and end of soybean cultivation, respectively, and 2 and 1 species at the beginning and end of the cover cultivation, respectively.

Table 6. Sorensen and Jaccard similarity coefficient of weeds in crop rotations in Chapadão do Sul, MS, in the $2016 / 2017$ harvest.

\begin{tabular}{|c|c|c|c|c|c|c|c|c|c|c|c|c|}
\hline \multirow{3}{*}{ Index } & \multicolumn{6}{|c|}{ Soy } & \multicolumn{6}{|c|}{ Cover } \\
\hline & \multicolumn{3}{|c|}{ October } & \multicolumn{3}{|c|}{ January } & \multicolumn{3}{|c|}{ February } & \multicolumn{3}{|c|}{ May } \\
\hline & $1 / 2$ & $1 / 3$ & $2 / 3$ & $1 / 2$ & $1 / 3$ & $2 / 3$ & $1 / 2$ & $1 / 3$ & $2 / 3$ & $1 / 2$ & $1 / 3$ & $2 / 3$ \\
\hline Jaccard & 0.29 & 0.46 & 0.50 & 0.50 & 0.43 & 0.75 & 0.18 & 0.33 & 0.50 & 0.12 & 0.20 & 0.13 \\
\hline Sorenson & 0.45 & 0.63 & 0.67 & 0.67 & 0.60 & 0.86 & 0.30 & 0.50 & 0.67 & 0.22 & 0.33 & 0.24 \\
\hline
\end{tabular}

1/Management 1; 2/Management 2; 3/Management 3. 


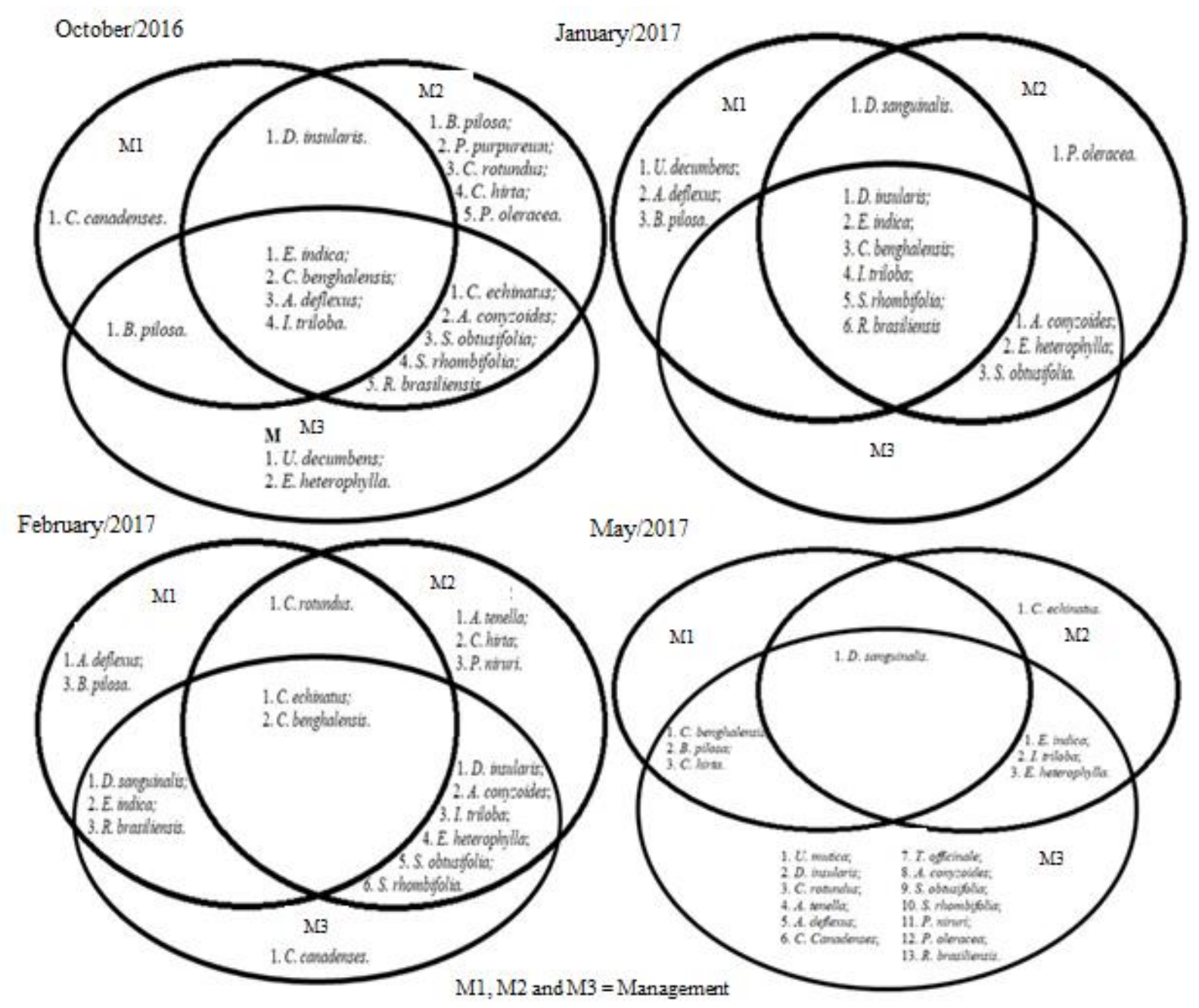

Figure 2. Venn diagram, illustrating the exclusive and shared weed species in the soybean crop and its successions in Chapadão do Sul/MS in the 2016/2017 harvest.

\section{Discussion}

Identifying weed species present in no-tillage and minimum tillage areas is important because the knowledge allows for weed control based on the infestation characteristics and intensity of each weed (Albuquerque et al. 2013; Zanuncio et al. 2013).

The weed species spectrum found in this survey (Table 1) does not differ from what occurs in soybean production fields, both in terms of monocotyledons such as Urochloa plantaginea, U. decumbens, Cenchrus echinatus, Digitaria spp., and Eleusine indica, as well as dicotyledons, including Alternanthera. tenella, Amaranthus spp., Cardiospermum halicacabum, Bidens pilosa, Commelina spp, Conyza spp., Euphorbia heterophylla, Ipomoea spp., Raphanus raphanistrum, Richardia brasiliensis, Sida spp., and Silene latifolia, among many others (Karam et al. 2012).

The species Ageratum conyzoides, B. pilosa, Commelina benghalensis, C. echinatus, Digitaria insularis, Digitaria sanguinalis, E. indica, Ipomoea triloba, and Senna obtusifolia presented relative importance indices $>30 \%$ in most management systems. Notably, management of the areas directly interferes with the germinal flow; some species stand out in each collection season due to several factors, including species characteristics, climate, seed bank, crop development, and the control period (Albuquerque 2006).

The families with the highest occurrence rates were Poaceae and Asteraceae, followed by Amaranthaceae and Euphorbiaceae (Table 1). Similar to these data, weed phytosociology in soybean cultivation was verified in two soil management systems, with high density of the species Brachiaria plantaginea, Euphorbia heterophylla, Ipomoea sp., Cyperus rotundus, and Digitaria horizontalis (Fialho et al. 2011). Additionally, in an area where there was resistant soybean and susceptible to glyphosate, 16 weed species belonging to 10 families were found, the main species belonging to Poaceae and Asteraceae, with 5 
and 3 species, respectively. The main species found were Bidens spp, Conyza spp, Euphorbia heterophylla, and Commelina benghalensis (Dias et al. 2018).

The species with relative importance indices $>30 \%$ within management area 1 were $D$. insularis, $E$. indica, $C$. benghalensis, D. sanguinalis, $A$. deflexus, and B. pilosa. The research area had been using glyphosate for several years, with a drying application before sowing and one or two applications during soybean cultivation, depending on field evaluation. Continued pressure from the use of an active ingredient may have led to the selection of resistant weeds. It is known that the repeated and continuous use of glyphosate results in tolerant weeds such as Commelina sp., and resistant species such as $C$. bonariensis, $C$. canadensis, $C$. sumatrensis, and D. insularis being selected (Bianchi, Vargas, and Rizzardi 2008). It is necessary to have criteria within this management area, mainly due to the use of glyphosate, as 48 cases of weed species with resistance to this active ingredient have been reported (HEAP, 2020a), 16 of which are in Brazil (HEAP, 2020b).

This trend presence of S. obtusifolia in the management areas 2 and 3 reveals that the species was well distributed in these areas, suggesting that attention towards its management is needed, as it can cause losses to soybean yield of $30 \%$ when there are three plants per $\mathrm{m}^{2}$. The presence of weeds can reduce crop productivity; however, sufficient information is not available on species diversity. It was found that the presence of one $B$. plantaginea plant per $\mathrm{m}^{2}$ can reduce the productivity of a soybean crop by $50 \%$ (Silva et al. 2009).

A. deflexus was present in all three management areas during the first survey, but with relative importance indices $<20 \%$, prevailing only in management area 1 . Its RI increased in the second round of sampling, at which point the soybeans were already at the end of their cycle (Table 3). Carvalho and Christoffoleti (2008) found five species of Amaranthus spp. (among them A. deflexus), with a density of 40 plants per $\mathrm{m}^{2}$, suggesting that the species present in greater density may not necessarily possess greater competition strength. High vigor during initial growth, efficient root system, seed dormancy, and the ability to host phytopathogens are the factors that also need to be considered.

Even with a relative importance index $<15 \%$, Poinsettia/Milkweed ( $E$. heterophylla) was present in management areas 2 and 3 (Table 2 and 3), and monitoring it was necessary due to its resistance to PROTOX and ALS inhibitors (HEAP, 2020a). In a study by Meschede et al. (2002), in the State of Paraná daily yield losses of $5.15 \mathrm{~kg} \mathrm{ha}^{-1}$ of a soybean crop were observed with the presence of $E$. heterophylla, while its absence represented a daily productivity gain of $7.27 \mathrm{~kg} \mathrm{ha}^{-1}$.

In general, for B. pilosa, I. triloba, C. hirta, E. heterophylla, S. rhombifolia, P. olaracea, and $R$. brasiliensis, the results show low frequencies and densities within the management areas and raised periods. Careful management is required of the above species, especially in areas of cotton rotation, as is the case in management area 1 , as B. pilosa and E. heterophylla have been resistant to ALS inhibitor herbicides (Agostinetto and Vargas 2009). The presence of I. triloba and S. obtusifolia can lead to losses of $33 \%$ and $55 \%$ in soybean yield, respectively, as well as a $60 \%$ reduction in productivity for the Embrapa-62 cultivar (Voll et al. 2002).

The results of the weed phytosociology performed on the cover crops in succession to the main crop (Tables 4 and 5) indicate the importance of integrated weed management, as crop rotation selects, and influences weed germination following commercial uses. The biological effect of mulching can also influence the behavior of spontaneous plants, since the presence of dead cover, and the associated increase in organic matter, generates conditions for many organisms (microorganisms, insects, rodents, etc.) which can use seeds and seedlings as sources of energy to thrive (Noce et al. 2008).

From the total number of individuals found in the weed phytosociology, $67.6 \%, 17.9 \%$, and $14.5 \%$ were observed in treatments 3 (Crotalaria), 1 (U. decumbens), and 2 (millet), respectively. Foltran et al. (2010) verified a lower incidence of weeds in several crop rotation systems with Urochloa grass in the soil, when compared to areas that presented fallow zones, or with other cover crops which produced less mulch than Crotalaria in their rotation system.

The IR $>40 \%$ observed for some species of the Poacea family (Tables 4 and 5), indicate that they are in the area occupation pattern. Inclusively facilitating adopting localized management practices (Souza et al. 2008) can reduce the volume of applied herbicides that can reach the soil (Balastreire and Baio 2001). $C$. benghalensis, which reached an IR index $>30 \%$ in all evaluated months, requires special attention in its 
management because of its reproductive characteristics. Wilson (1981) reported that the difficulty of controlling plants of the Commelinaceae family can be attributed to their double reproduction mechanisms: by seed and by rooting at their nodes. According Vega et al. (2000), the difficulty of controlling this species is directly related to its development stage. When herbicide application was divided between various development stages, Krolikowski et al. (2017) did not find any difference between the treatments for stages 22 and 51. According to Fleck et al. (2008), this result shows that in order to more efficiently control this species, it is necessary to have knowledge about the development stages, densities, herbicide dose, management strategies, and application conditions.

The presence or absence of $D$. insularis, I. trilobal, and E. indica (Table 4 and 5) was observed in management areas 1 and 2, with IR indices $>30 \%$, indicating presence both by frequency and by density. Gazziero et al. (2012) verified that the presence of $6-8$ plants per $\mathrm{m}^{2}$ of $D$. insularis during the soybean cycle can reduce its productivity by up to $44 \%$.

The succession with Crotalaria (management area 3) found large amounts of weed species, of which, most possess resistance to certain groups of herbicides. Plants with an IR index $>30 \%$ in management area 3 (Table 4 and 5) such as $C$. echinatus, $C$. benghalensis, $A$. conyzoides, D. sanguinalis, and S. obtusifolia, had higher RD indices than RF, indicating that they are present in defined areas (reboilers), and with elevated RA.

Thus, it is important to monitor and identify germinal flows in the succession system as a way of adopting phytosanitary measures for managing the species to be planted in the crop rotation system. It is not always justified to adopt crops with economic potential as crop covering. It is often necessary to prioritize crops which can reduce the number of invasive species, such as those with colonizing or allopathic characteristics, fast between-row closing, and the ability to supply mulch in order to reduce the germinal flow, and consequently the seed bank expression.

The greatest similarity (Figure 2, Table 6) was found between management areas 2 and 3, which could be attributed to the similarities in the management of these two areas. In management area 1 , the presence of cotton cultivation preceding soybean, provides a more differentiated weed control environment. The adoption of similar weed management between years of soybean cultivation was the reason for the high similarity justified by Dias et al. (2018), while the low similarity found between the initial and pre-harvest evaluations of sunflower was attributed to the different growing seasons of the two driving environments (Adegas et al. 2010).

\section{Conclusions}

The management area using the cotton/soybean/Urochloa rotation had less weed species than other areas. The species $C$. echinatus, $D$. insularis, $D$. sanguinalis, $E$. indica, and $C$. benghalensis have the highest phytosociological indices among the monocotyledons. Attention should be directed towards managing the dicotyledons A. deflexus, C. canadenses, and S. obtusifolia, despite low index scores because of cases of herbicide resistance. The highest indices of similarity were found between management areas 2 and 3 , which did not rely on cotton cultivation prior to soybeans.

Authors' Contributions: CASTRO, M.A.: conception and design, acquisition of data, analysis and interpretation of data, drafting the manuscript, final approval; LIMA, S.F.: analysis and interpretation of data, drafting the manuscript, final approval; TOMQUELSKI, G.V.: analysis and interpretation of data, drafting the manuscript, final approval; ANDRADE, M.G.O.: drafting the manuscript, final approval; MARTINS, J.D.: drafting the manuscript, final approval.

Conflicts of Interest: The authors declare no conflicts of interest.

Ethics Approval: Not applicable.

Acknowledgments: Not applicable.

References

ADEGAS, F.S., et al. Levantamento fitossociológico de plantas daninhas na cultura do girassol. Planta Daninha. 2010, 28(4), 705-716.

AGOSTINETTO, A. and VARGAS, L. Resistência de plantas daninhas a herbicidas no Brasil. Passo Fundo: Gráfica Editora Berthier, 2009. 
ALBUQUERQUE, J.A.A. Interferência de plantas daninhas e do feijão sobre a cultura da mandioca. Viçosa: UFV, 2006.

ALBUQUERQUE, J.A.A., et al. Fitossociologia e características morfológicas de plantas daninhas após cultivo de milho em plantio convencional no cerrado de Roraima. Revista Agro@mbiente. 2013, 7(3), 313-321. http://dx.doi.org/10.18227/1982-8470ragro.v7i3.1392

ÁVILA, J., et al. Cover crops change the phytosociology of weeds and the banana yield. Revista de Agricultura Neotropical. 2020, 7(1), 53-59. https://doi.org/10.32404/rean.v7i1.3349

BALASTREIRE, L.A., and BAIO, F.H.R. Avaliação de uma metodologia prática para o mapeamento de plantas daninhas. Revista Brasileira Engenharia Agrícola e Ambiental. 2001, 5(2), 349-352. https://doi.org/10.1590/\$1415-43662001000200029

BIANCHI, M.A.L., VARGAS, M. and RIZZARDI, A., 2008. Manejo e controle de plantas daninhas resistentes ao glyphosate no Brasil. In: Congresso Brasileiro da Ciência das Plantas Daninhas: 2008, Ouro Preto. Ouro Preto: SBCPD, pp. 223-231.

BRAUN-BLANQUET, J. Fitosociología, bases para el estudio de las comunidades vegetales. Madrid: H. Blume, 1979.

BRAZ. P.B., et al. Componentes de produção e rendimento de soja em função da época de dessecação e do manejo em pós-emergência. Revista Brasileira de Herbicidas. 2010, 9(2), 63-72. https://doi.org/10.7824/rbh.v9i2.83

BRIGHENTI, A.M. Manual de identificação e manejo de plantas daninhas em cultivos de cana-de-açúcar. Juiz de Fora: Embrapa Gado de Leite, 2010. Available from: https://ainfo.cnptia.embrapa.br/digital/bitstream/item/26157/1/Manual-Brighenti.pdf

BRIGHENTI, A.M., et al. Cadastramento fitossociológico de plantas daninhas na cultura do girassol. Pesquisa Agropecuária Brasileira. 2003, 38(5), 651-657. https://doi.org/10.1590/S0100-204X2003000500014

CARVALHO, S.J.P. and CHRISTOFFOLETI, P.J. Competition of Amaranthus species with dry bean plants. Scientia Agricola. 2008, 65(3), $239-245$. https://doi.org/10.1590/S0103-90162008000300003

CASTRO, G.S., et al. Sistemas de produção de grãos e incidência de plantas daninhas. Planta Daninha. 2011, 29, 1001-1010.

https://doi.org/10.1590/S0100-83582011000500006

CASTRO. M.A., et al. Atributos físico-hídricos do solo ocupado com pastagem degradada e floresta nativa no Cerrado Sul-Mato-Grossense. Brazilian Geographical Journal: Geosciences and Humanities research medium. 2012, 3(2), 498-512.

CONCENÇO, G., et al. Phytosociological surveys: tools for weed science? Planta Daninha. 2013, 31(2), 469-482. https://doi.org/10.1590/S0100$\underline{83582013000200025}$

DIAS, M.F., et al. Phytosociological survey of weeds in glyphosate resistente and susceptible soybean cultivation areas. Revista Brasileira de Ciências Agrárias. 2018, 13(4), e5592. https://doi.org/10.5039/agraria.v13i4a5592

FERREIRA L.R., et al. Manejo de plantas daninhas na Integração Lavoura-Pecuária-Floresta. Informe Agropecuário. 2010, 31(257), 37-46.

FIALHO, C.M.T., et al. Fitossociologia da comunidade de plantas daninhas na cultura da soja transgênica sob dois sistemas de preparo do solo. Scientia Agraria. 2011, 12(1), 9-17. http://dx.doi.org/10.5380/rsa.v12i1.33634

FOLTRAN, R., et al., 2010. Levantamento fitossociológico das comunidades de plantas infestantes em diferentes sistemas de rotação de culturas. In: Congresso Brasileiro da Ciência das Plantas Daninhas: 2010, Ribeirão Preto. Ribeirão Preto: SBCPD, p. 1115.

FLECK, N.G., et al. Controle de papuã (Brachiaria plantaginea) em soja em função da dose e da época de aplicação do herbicida clethodim. Planta Daninha. 2008, 26(2), 375-383. https://doi.org/10.1590/S0100-83582008000200014

GAZZIERO D.L.P., et al., 2012. Efeitos da convivência do capim-amargoso na produtividade da soja. In: Congresso Brasileiro da Ciência das Plantas Daninhas: 2012, Campo Grande. Campo Grande: SBCPD, pp. 345-350.

GUGLIERI-CAPORAL, A., CAPORAL, F.J.M. and POTT, A. Phytosociology of sown pasture weeds under two levels of degradation in Brazilian savanna areas, Mato Grosso do Sul State, Brazil. Pesquisa Agropecuária Tropical. 2010, 40(3), 312-321. https://doi.org/10.5216/patv40i3.6051

HEAP, I. The International Herbicide-Resistant Weed Database. Online. 2020a. Available from: www.weedscience.org

HEAP, I. The International Survey of Herbicide Resistant Weeds. Online. 2020b. Available from: www.weedscience.org

KARAM, D., et al. Plantas daninhas presentes na cultura do milho no estado do Rio Grande do Sul. Sete Lagoas: Embrapa Milho e Sorgo, 2012. Available from: https://ainfo.cnptia.embrapa.br/digital/bitstream/item/81329/1/doc-147.pdf

KROLIKOWSKI, V., CARVALHO, F.T. and TEODORO, P.E. Comportamento morfofisiológico de Commelina benghalensis em resposta a herbicidas aplicados em pós-emergência. Bioscience Journal. 2017, 33(2), 268-275. https://doi.org/10.14393/BJ-v33n2-32845

LIMA, S.F., et al. Fitossociologia de plantas daninhas em convivência com plantas de cobertura. Revista Caatinga. 2014, 27(2), 37-47.

MACHADO, B.L.R., et al. Levantamento de plantas daninhas em lavoura de arroz irrigado com pivô em Cachoeira do Sul - RS. Ciência e Natura. 2020, 42, e43. http://dx.doi.org/10.5902/2179460X40649

MESCHEDE, D., et al. Período Crítico de Interferência de Euphorbia heterophylla na cultura da soja sob baixa densidade de semeadura. Planta Daninha. 2002, 20(3), 381-387. https://doi.org/10.1590/S0100-83582002000300008

MUELLER-DOMBOIS, D. and ELLENBERG, H. Aims and methods of vegetation ecology. New York: John Willey and Sons, 1974. 
MYERS, J.P., et al. Concerns over use of glyphosate-based herbicides and risks associated with exposures: a consensus statement. Environmental Health. 2016, 15(1), 1-13. https://doi.org/10.1186/s12940-016-0117-0

NOCE, M.A., et al. Influência da palhada de gramíneas forrageiras sobre o desenvolvimento da planta de milho e das plantas espontâneas. Revista Brasileira de Milho e Sorgo. 2008, 7(3), 265-278. https://doi.org/10.18512/1980-6477/rbms.v7n3p265-278

ODUM, E.P. Ecologia. Rio de Janeiro: Interamericana, 1985.

OLIVEIRA, M.F., et al. Efeito da palha e da mistura atrazine + metolachlor no controle de plantas daninhas na cultura do milho, em sistema de plantio direto. Pesquisa Agropecuária Brasileira. 2001, 36(1), 37-41. https://doi.org/10.1590/S0100-204X2001000100005

PITELLI, R.A. O termo planta-daninha. Planta Daninha. 2015, 33(3), 622-623. https://doi.org/10.1590/S0100-83582015000300025

PROCÓPIO, S.O., et al. Utilização de chlorimuron-ethyl e imazethapyr na cultura da soja Roundup Ready ${ }^{\circledR}$. Planta Daninha. 2007, 25(2), 365373. https://doi.org/10.1590/S0100-83582007000200017

RICHETTI, A. Viabilidade econômica da cultura da soja na safra 2012/2013, em Mato Grosso do Sul. Dourados: Embrapa Agropecuária Oeste, 2015.

RODRIGUES, W.C. DivEs - Diversidade de Espécies: an ecological software: v.4.0. 2017. Available from: http://dives.ebras.bio.br/downloads.aspx

SANTOS, C.S., et al. Levantamento fitossociológico de plantas daninhas na cultura da laranja. Journal of Agronomic Sciences. 2015, 4(2), 50-59.

SCHMIDT, D.A., et al. Levantamento de plantas daninhas em lavoura de soja irrigado com pivô em Cachoeira do Sul - RS. Ciência e Natura. 2020, 42, e43. http://dx.doi.org/10.5902/2179460X40654

SILVA, A.F., et al. Período anterior à interferência na cultura da soja-RR em condições de baixa, média e alta infestação. Planta daninha. 2009, 27(1), 57-66. https://doi.org/10.1590/S0100-83582009000100009

SILVA, T.R.G., et al. Levantamento fitossociológico de plantas daninhas na cultura do maracujá. Revista ambientale. 2019, 11(2), 34-41. https://doi.org/10.34032/ambientale.v11i2.96

SOARES, D.J., et al., 2010. Avaliação de programas alternativos de manejo de plantas daninhas utilizando herbicidas pré-emergentes na soja TG. In: Congresso Brasileiro da Ciência das Plantas Daninhas: 2010, Ribeirão Preto. Ribeirão Preto: SBCPD, pp. 1508-1512.

SOUZA, G.S., et al. Variabilidade espacial de atributos químicos em um Argissolo sob pastagem. Acta Scientiarum. Agronomy. 2008, 30(4), 589596. https://doi.org/10.4025/actasciagron.v30i4.5322

VAN BRUGGEN, A.H.C., et al. Environmental and health effects of the herbicide glyphosate. Science of The Total Environment. 2018, 616-617, 255-268. https://doi.org/10.1016/i.scitotenv.2017.10.309

VENDRUSCOLO, E.P., et al. Análise econômica da produção de alface crespa em cultivo sucessivo de plantas de cobertura em sistema de plantio direto. Revista Brasileira de Ciências Agrárias. 2017, 12(4), 458-463. https://doi.org/10.5039/agraria.v12i4a5478

VEGA, M.H., et al. Control de Commelina erecta L. con herbicidas postemergentes com el objectivo de su uso en cultivo de soja transgénica. Planta Daninha. 2000, 18(1), 51-56. http://dx.doi.org/10.1590/S0100-83582000000100005

VIDAL, R.A. and MEROTTO JUNIOR., A. Herbicidologia. Porto Alegre: Evangraf, 2001.

VOLL, E., et al. Competição relativa de espécies de plantas daninhas com dois cultivares de soja. Planta Daninha. 2002, 20(1), 17-24. https://doi.org/10.1590/S0100-83582002000100003

ZANUNCIO, A., et al. Alelopatia de adubos verdes sobre Cyperus rotundus. Revista de Ciências Agrárias. 2013, 36(4), 441-446.

WILSON, A.K. Commelinaceae - a review of the distribution, biology and control of the important weeds belonging to this family. Tropical Pest Management. 1981, 27(3), 405-418. https://doi.org/10.1080/09670878109413812

Received: 31 October 2019 | Accepted: 20 August 2020 | Published: 28 January 2021 